\title{
Rebecca Esterson*
}

\section{Allegory and Religious Pluralism: Biblical Interpretation in the Eighteenth Century}

https://doi.org/10.1515/jbr-2018-0001

\begin{abstract}
The Christian discourse of the literal and spiritual senses in the Bible was, in the long eighteenth century, no less tied to perceptions of Jewish interpretive abilities than it had been previously. However, rather than linking Jews with literalism, in many cases the early modern version of this discourse associated Jews with allegory. By touching upon three moments in the reception history of the Bible in the eighteenth century, this article exhibits the entanglement of religious identity and biblical allegory characteristic of this context. The English Newtonian, William Whiston, fervently resisted allegorical interpretations of the Bible in favor of scientific and literal explanations, and blamed Jewish manuscript corruption for any confusion of meaning. Johan Kemper was a convert whose recruitment to Uppsala University reveals an appetite on the part of university and governmental authorities for rabbinic and kabbalistic interpretive methods and their application to Christian texts. Finally, the German Jewish intellectual Moses Mendelssohn responded to challenges facing the Jewish community by combining traditional rabbinic approaches and early modern philosophy in defense of a multivocal reading of biblical texts. Furthermore, Mendelssohn's insistence on the particularity of biblical symbols, that they are not universally accessible, informed his vision for religious pluralism. Each of these figures illuminates not only the thorny plight of biblical allegory in modernity, but also the ever-present barriers and passageways between Judaism and Christianity as they manifested during the European Enlightenment.
\end{abstract}

Keywords: allegory; literalism; eighteenth century; Jewish; Christian; biblical interpretation; Enlightenment; William Whiston; Johan Kemper; Moses Mendelssohn.

\section{Introduction}

Recent scholarship has contributed to our understanding of post-Reformation approaches to the Bible and Early Modern Jewish-Christian relations in a number of ways. Michael Legaspi and Jonathan Sheehan, for instance, explore the academic and cultural re-centering of biblical studies in European universities and

*Corresponding author: Rebecca Esterson, Graduate Theological Union, Center for Swedenborgian Studies, Berkeley, CA, USA, e-mail: resterson@gtu.edu 
other centers of learning. ${ }^{1}$ This turn to reading the Bible as cultural heritage, or as part of the emerging humanities, arose alongside the scientific revolution. The interest in mathematical certainty and mechanistic principles, according to the argument of Peter Harrison, was inspired by a hermeneutical preference for the plain sense of Scripture and a decisive rejection of the allegorical methods of earlier eras. ${ }^{2}$ Stephen Burnett, for his part, describes the Reformation-era removal of Jews and Judaism from Hebrew learning and translation in Christian circles. ${ }^{3}$ Adam Sutcliffe and Naomi Seidman argue that despite this attempted divorce from things Jewish, a deep-seated and sweeping ambivalence persisted. Sutcliffe writes: "Throughout the Enlightenment the question of the status of Judaism and of Jews was a key site of intellectual contestation, confusion, and debate." ${ }^{4}$ This ambivalence manifested both among those that challenged traditional Christian interpretations of the Bible and among those that defended them. Against the backdrop of this scholarship, this article argues that rather than witnessing the final demise of allegory, as Harrison puts it, the eighteenth century saw a discourse emerge about allegorical exegesis that was itself one of these key sites of radical ambivalence concerning Jews and Judaism.

1 Michael Legaspi traces the work of eighteenth-century academics, such as Johann David Michaelis, who consign biblical studies to the humanities, reading the Bible as they did classical poetry, thereby making Moses, as it were, the Homer of classical Israel. See Michael C. Legaspi, The Death of Scripture and the Rise of Biblical Studies (Oxford University Press on Demand, 2010). Jonathan Sheehan argues that the rise of the "cultural Bible" in England and Germany was not motivated by secular impulses, but rather utilized a sophisticated set of instruments inspired by confessional contexts. See Jonathan Sheehan, The Enlightenment Bible: Translation, Scholarship, Culture (Princeton University Press, 2005). Christopher Ocker, for his part, demonstrates continuities between late medieval and early modern interest in the grammatical and rhetorical elements of biblical texts. The collapse of the literal and spiritual senses that began in the Middle Ages informs the interest in biblical poetics that develops in the following centuries, and demonstrates a corresponding collapse of human and divine authorship. See Christopher Ocker, Biblical Poetics before Humanism and Reformation (Cambridge University Press, 2002).

2 Peter Harrison, The Bible, Protestantism, and the Rise of Natural Science (Cambridge: Cambridge University Press, 1998). Hans Frei also describes this phenomenon: "Despite the influence of Pietism, the fate of 'spiritual' reading and thus of double meaning in the interpretation of scripture in the later eighteenth century was finally as dim as that of the principle of interpretation through tradition, evaporating the remnants of whatever mystical-allegorical reading on the part of Protestants had survived the seventeenth century." See Hans Frei, The Eclipse of Biblical Narrative: A Study in Eighteenth and Nineteenth Century Hermeneutics (New Haven: Yale University Press, 1974), 55.

3 Stephen G. Burnett, Christian Hebraism in the Reformation Era (1500-1660): Authors, Books, and the Transmission of Jewish Learning (Boston: Brill, 2012).

4 Adam Sutcliffe, Judaism and Enlightenment (Cambridge: Cambridge University Press, 2003), 5. See also Naomi Seidman, Faithful Renderings: Jewish-Christian Difference and the Politics of Translation (Chicago: University of Chicago Press, 2006), 115-52. 
Christian allegorical interpretation of the Bible has relied on narratives about the nature of Jewish texts and Jewish interpretations since its first instance in Paul's Epistle to the Galatians. Paul's interpretation of the Genesis matriarchs Sarah and Hagar, which contrasts slavery, the law, and the flesh on one hand, with freedom from the law and the power of the spirit on the other, set the tone for Christian discourse about the Bible and about Jews for the ages. ${ }^{5}$ With the emergence of Jerome's Latin translation of the Bible in the late fourth century, Jews were further characterized as literalists. Jerome's reliance on Jewish interlocutors for this translation brought with it the threat of accusations of Judaizing. His defense was to attack, not only the traditions of Jews, but most importantly, their ability to properly interpret the Bible. In his view, Jewish understanding of Scripture was limited to the literal or historical sense, while Christians alone had access to the allegorical, spiritual meaning. The success of this characterization of Jewish and Christian interpretive abilities can be traced from Jerome, through Augustine, to Martin Luther, and detected in the thought of countless religious and political figures in between. The trope became entangled with Christian selfidentity and claims of doctrinal authority and occupied a central place in Christian definitions of Judaism as a carnal, worldly, and spiritually deficient tradition. As author Megan Hale Williams writes, Jerome's work “contributed greatly to the emergence of a new Christian discourse of the Jew, and to its persistence in the Latin West for at least a millennium." 6

It is somewhat unexpected, therefore, to find in the sixteenth to the eighteenth centuries the emergence of a viewpoint among certain influential thinkers in Western Europe that associated Christian interpretation of the Bible with literalism and rabbinic interpretation with allegory. This was a reversal of the previous scheme. As Harrison and others have demonstrated, Christian interest in biblical literalism had been on the rise since medieval times, but reached new heights in early modernity due to factors such as the Protestant Reformation's turn to sola Scriptura, the success of Pietistic movements, and the scientific divergence from metaphysical explanations. Many came to the view that God's words and intentions were apparent to each person in his/her own language, bypassing the requirement for clerical interpretation and its potential for corruption. Every believing reader could access the plain truth, available from God as set out on the page; "God is His own interpreter, And He will make it plain" the popular hymn

5 See Galatians 4:21-5:26.

6 Megan Hale Williams, "Lessons from Jerome’s Jewish Teachers: Exegesis and Cultural Interaction in Late Antique Palestine," in Jewish Biblical Interpretation and Cultural Exchange: Comparative Exegesis in Context, eds. Natalie Dormann and David Stern (Philadelphia: University of Pennsylvania Press, 2008), 77. 
proclaimed. ${ }^{7}$ Then, in an astounding turn, given the history summarized above, allegory and figuration were consigned to the methods of the Jews.

This new way of characterizing Jewish interpretation was often derisive, as in Robert Hooke's words distancing his work in microscopy from the perceived obsession with biblical minutiae on the part of rabbis: "Rabbins find out Caballisms, and Enigmas in the figure, and placing of Letters, where no such thing lies hid; whereas in Natural forms there are some so small, and so curious, and their design'd business so far removed from the reach of our sight, that the more we do magnify the object, the more excellencies and mysteries do appear." ${ }^{8}$ John Toland's accusation against early Christian interpreters rang a similar tone: "Everyone knows how the primitive Christians, in a ridiculous imitation of the Jews, turn'd all the Scripture into Allegory." 9

However, the association between Jews and allegory was also made more positively. Christian thinkers often exploited Jewish sources out of a perception that they contained an interpretive depth unmatched in the Christian commentaries. Many learned experts believed the mystical books of the Jews, such as the Zohar, contained ancient wisdom from distant lands, supposing them to be much older than we now know them to be. ${ }^{10}$ Some even believed Jewish exegesis to be the foundation upon which the gospels were written, such that the English theologian and Mishna enthusiast, William Wotton, concluded: "If I had ever had an Opportunity, I wou'd most certainly have gone thro' the New Testament under a Jew [...] that they understand it infinitely better than we do." ${ }^{11}$ Thus, while Jewish interpretation was derided by some for its association with allegory, it was appropriated by others precisely for its connection to hidden depths of

7 William Cowper, “God Moves in a Mysterious Way," in Twenty-six Letters on Religious Subjects to Which Are Added Hymns, ed. John Newton (Dublin: W. Gilbert, 1780), 252.

8 From Robert Hooke's Micrographia as quoted in Harrison, The Bible, 197 (emphasis in the original).

9 John Toland, Christianity not Mysterious (London: Samuel Buckley, 1696), 115.

10 Belief in the early dating of the Zohar persisted into the eighteenth and nineteenth centuries, especially in Christian kabbalistic circles, where it was believed to be part of an ancient wisdom, predating the New Testament. Guy Stroumsa argues that the eighteenth-century fascination with ancient cultures came hand in hand with a fascination with foreign cultures and notes that the texts, practices, and history of the Jews, as "foreigners within," became the locus of decoding for Christian intellectuals. See Guy Stroumsa, A New Science: The Discovery of Religion in the Age of Reason (Cambridge, MA: Harvard University Press, 2010), 41. There were challenges to the early dating of the Zohar, for instance, in the work of Venetian rabbi, Leon Modena. See Yaacob Dwek, The Scandal of Kabbalah (Princeton, NJ: Princeton University Press, 2011).

11 From William Wotton's Miscellaneous Discourses, as quoted in David Ruderman, Connecting the Covenants: Judaism and the Search for Christian Identity in Eighteenth-Century England (Philadelphia: University of Pennsylvania Press, 2007), 85. 
meaning, revealing a tension within the intellectual culture of the eighteenth century Christendom.

This article will demonstrate how the traditional Christian discourse of the literal and spiritual senses in the Bible was, in the long eighteenth century, no less tied to the "discourse of the Jew" than it had been previously. ${ }^{12}$ The early modern version of this discourse did, however, bring with it a plot twist, linking Jews with allegory, or the idea that the biblical text might be saying something else [allos agoria]. Anxieties surrounding the religious "other" are matched with anxieties about a text that might mean something other than what it says. By touching upon three moments in the reception history of the Bible in Enlightenment Europe, this article demonstrates the entanglement of religious identity and biblical allegory characteristic of this context.

We will begin with the English Newtonian, William Whiston, who fervently resisted allegorical interpretations of the Bible in favor of scientific and literal explanations, and blamed Jewish manuscript corruption for any confusion of meaning. We will then consider the work of the convert Johan Kemper, whose recruitment to Uppsala University reveals an appetite on the part of university and governmental authorities for rabbinic and kabbalistic interpretive methods and their application to Christian texts. Finally, the German Jewish intellectual Moses Mendelssohn responds to challenges facing the Jewish community by combining traditional rabbinic approaches and early modern philosophy in defense of a multivocal reading. Furthermore, Mendelssohn's insistence on the particularity of biblical symbols, that they are not universally accessible, informed his vision for religious pluralism. None of these men are broadly representative of either Christian or Jewish exegesis in their time; biblical studies in the eighteenth century diverged in many directions and had no single spokesperson. Together, however, they illuminate not only the thorny plight of biblical allegory in modernity, but also the ever-present barriers and passageways between Judaism and Christianity as they manifest in the long eighteenth century. As Sutcliffe writes, attention to Jewish-Christian relations during the Enlightenment directs us to key intellectual and cultural sticking points: "the complexities clustered around Judaism are of central importance for a general understanding of the Enlightenment itself." ${ }^{13}$ The persistent concern with non-literal approaches to the Bible is one such sticking point, as the following figures demonstrate.

12 See, for instance, Deeana Klepper, The Insight of Unbelievers: Nicholas of Lyra and Christian Reading of Jewish Text in the Later Middle Ages (Philadelphia: University of Pennsylvania Press, 2007); Beryl Smalley, The Study of the Bible in the Middle Ages, 3rd ed. (Oxford: Basil Blackwell, 1983); and Williams, "Jerome’s Jewish Teachers."

13 Sutcliffe, Judaism and Enlightenment, 6. 


\section{William Whiston: Anti-Allegory, Anti-Judaism}

William Whiston's (1667-1752), singlehanded war on allegory utilized the latest in scientific discovery as well as the study of Hebrew and Judaism as arsenal. Whiston, like so many of his contemporaries, embodies the historian's familiar refrain that science and religion were not yet separate disciplines in the early eighteenth century. Whiston's work in biblical chronology, translation of Josephus, early church history, and biblical manuscript study interfaced with his work in mathematics and astronomy, was, in ways, unique to his age. Among his many books demonstrating this interface was his Astronomical Principles of Religion, Natural and Reveal'd, in which he applied his exegetical skills and scientific reasoning to the task of determining, among other things, the location of hell.14 This is but one example of how the Bible was explained anew by the pious scientists of early modernity, often in defense of the plain sense of the text.

Whiston's incorporation of astronomy into his exegesis was made possible by his mentorship with Isaac Newton. A student of Newton and successor to Newton as Lucasian Professor of Mathematics at Cambridge, Whiston inherited several of Newton's positions and interests regarding natural philosophy and theology. However, the question of how these two men aligned, or not, over their approaches to the Bible is yet to be settled, and a word should be said about this before proceeding.

James Force, whose research centers on Newton and his influence, argues that Whiston's approach to the Bible is essentially Newtonian in nature, and that Newton was a behind-the-scenes promoter of Whiston's Boyle lectures on biblical literalism, entitled “The Accomplishment of Scripture Prophecies.” Force's evidence for "Whiston's literal Newtonian interpretation" 15 has been challenged in more than one review, ${ }^{16}$ and the positive relationship between Newton and Whiston is disputed in a recent book by Jed Buchwald and Mordechai Feingold. ${ }^{17}$

14 Whiston determined that the place of darkness and fire described in Scripture could be none other than a "Comet, ascending from the Hot Regions near the Sun, and going into the Cold Regions beyond Saturn, with its long smoking Tail arising up from it, through its several Ages and Periods of revolving...” William Whiston, Astronomical Principles of Religion, Natural and Reveal'd: in Nine Parts (London: J. Senex and W. Taylor, 1717).

15 A phrase Force employs repeatedly. See for instance: James Force, William Whiston, Honest Newtonian (Cambridge: Cambridge University Press, 1985), 83.

16 See, for instance, the reviews of Force's William Whiston, Honest Newtonian by Simon Schaffer in The British Journal for the History of Science 19 (1986), 226-8; Anita Guerrini in The Journal of Religion 67, (1987), 100-1; and Mordechai Feingold in Eighteenth-Century Studies 21 (1987), 141-2. 17 Jed Z. Buchwald and Mordechai Feingold, Newton and the Origin of Civilization (Princeton: Princeton University Press, 2013), 333-8. On the similarity between Newton and Whiston's view of the Godhead, see Stephen Snobelen, “'God of Gods, and Lord of Lords:' The Theology of Isaac Newton's General Scholium to the Principia,” Osiris 16 (2001), 187-8. 
Furthermore, Whiston's biblical literalism bumps up against Newton's interest in alchemy and symbolism. Newton's symbolic interpretations of tabernacle and temple, for instance, suggests an approach somewhat different from Whiston's in its reliance on coded meaning. ${ }^{18}$

However, an important commonality between Newton and Whiston for our purposes, is their shared obsession with deciphering and preserving an uncorrupted version of the biblical text. Both men employed comparison between Greek, Latin and Hebrew versions of the Old Testament, and their criticism of the Hebrew Masoretic Text fell in line with broader accusations against rabbinic tradition surfacing at the time. Fundamentally, the exegetical writing of both men exhibited the conviction that the antiquity of a text or tradition was a demonstration of its truth. Born out of a Protestant distrust of tradition, eighteenth century thinkers such as these tended to view religious developments in both Christianity and Judaism from the second century on as corruptions. The Talmud and the Council of Nicaea alike came under scrutiny, and the scholar's aim was discovering the purest, most ancient, most holy Bible. Of the many conclusions that these two men came to, Arianism, or the rejection of the Trinitarian formula of Athanasius and the church fathers, was by far the most controversial and ended with Whiston's banishment from Cambridge University in 1710. Much more popular, and with farther reaching consequences, was Whiston's assault on allegorical interpretation, which he promoted with renewed vigor thereafter in London.

Whiston's views on allegory are best understood as a response to the attacks of Deism, which were triggered in part by the work of Thomas Burnet and his controversial Telluris Theoria Sacra, published in the 1680s. On the one hand,

18 See especially Newton's Prolegomena ad lexici prophetici partem secundam in quibus agitur De forma sanctuarij Iudaici. Ms. 434, The Babson College Grace K. Babson Collection of the Works of Sir Isaac Newton, Huntington Library, San Marino, California. He writes: "It is universally accepted that future events are foreshadowed by the prescriptions of the law, and the Apostle Paul amply testifies to this in Colossians 2.17 and Hebrews 8.5 and 9.23. That is why those prescriptions are more fitted than the natural World to be a system of things from which the Prophets could derive types; it is also why the Apocalypse is full of these types, and therefore these prescriptions and the Apocalypse explain each other like twin prophecies of the same things, and cannot be properly understood apart from each other. For that book, sealed by the hand of Him who sits upon the throne, is the very book of the law, as will be shown later, and its seals are opened in the Apocalypse. We must now therefore study the world of Israel, and expound the significance of its parts and ceremonies. And above all we must survey the Sanctuary in which the requirements of the law were carried out. This had three phases: the Tabernacle down to the time of Solomon, the first temple down to the Babylonian captivity, and the second temple down to the captivity under the Romans. We must get to know their design, if we want to have a proper grasp of their significance.” Accessed on June 26, 2016: http://www.newtonproject.sussex.ac.uk/ view/texts/normalized/THEM00079. 
Whiston and Burnet had much in common, as they both attempted explanations of biblical accounts using mechanistic principles. Burnet, for his part, worked to do this with as little recourse to special providence as possible, which made the Hexamaeron, or six-day creation, a particularly difficult stumbling block. ${ }^{19} \mathrm{He}$ believed that the world was created in the order and manner described in Genesis, but that the length of time itself could only be understood allegorically. That it did not literally take six days was no innovation. As far back as Augustine, Christian exegetes had been relativizing the measurement of time in the beginning. But Burnet's turn to allegory in an otherwise scientific study stood out. His qualification was viewed as a weakness by responding Deists and theists alike. ${ }^{20}$ Whiston thought he could do better, and was determined to defend the biblical account of creation without the crutch of Burnet's "parabolick sense." ${ }^{21}$ Whiston's support of the Genesis events relied on theories of the impact of comets. The impact of colliding spheres on their natural course rapidly changed the landscape of the earth, and the six days of creation describe exactly what it would have looked like to an observing set of eyes. No allegory is needed; the text means precisely what it says.

That the biblical text could have only one meaning, and that its meaning was to be understood literally, became fundamental to Whiston's overall hermeneutical approach. He outlined this approach in a publication responding to Burnet's and pointedly titled $A$ New Theory of the Earth, from its Original, to the Consummation of All Things, Where the Creation of the World in Six Days, the Universal Deluge, and the General Conflagration, as laid down in the Holy Scriptures, are Shewn to be perfectly agreeable to Reason and Philosophy. Among his postulates for interpretation, Whiston writes that "The Obvious or Literal Sense of Scripture is the True and Real one, where no evident Reason can be given to the contrary." 22

19 The reception of Spinoza in seventeenth-century England triggered discussions about the reasonableness of belief in biblical miracles. Henry More and Ralph Cudworth, for instance, wrote in defense of miracles in responding to Spinoza. See Rosalie L. Colie, "Spinoza in England, 1665-1730,” Proceedings of the American Philosophical Society 107, no. 3 (1963), 183-219. Burnet's work attempted to straddle two positions seemingly at odds in Spinoza's wake: the inerrancy of Scripture and God's operation via the laws of nature.

20 Burnet had many critics, including Christianus Wagner, Herbert Crofts, and Erasmus Warren. On the Deist response to Burnet, see James Force, William Whiston, Honest Newtonian (Cambridge: Cambridge University Press, 1985), 35-8. See also William Poole, The World Makers: Scientists of the Restoration and the Search for the Origins of the Earth (Oxfordshire, UK: International Academic Publishers, 2010), 56-68.

21 William Whiston, A New Theory of the Earth, From its Original, to the Consummation of All Things, Where the Creation of the World in Six Days, the Universal Deluge, And the General Conflagration, As laid down in the Holy Scriptures, Are Shewn to be perfectly agreeable to Reason and Philosophy (London: J. Whiston and B. White, at Mr. Boyle's Head in Fleet-Street, 1755), 66.

22 Ibid., 66. 
Whiston's Boyle lectures as well as his 1724 follow-up book, The Literal Accomplishment of Scripture Prophecy, ${ }^{23}$ apply his methods to the Old Testament prophecies. Like Genesis, interpretation of prophetic literature had become a point of controversy amidst the challenges posed by Deism, especially for their reliance on double meanings. In order to meet this challenge Whiston set out to prove that messianic prophecies referred to events surrounding the birth, life and death of Jesus alone, and not to the immediate circumstances of the Judahite and Israelite kings and kingdoms to which they were pronounced. Traditional Christian reliance on more than one sense of Scripture was to be abandoned here, along with other patristic perversions: "I observe that the Stile and Language of the Prophets, as it is often peculiar and enigmatical, so it is always single and determinate, and not capable of those double Intentions, and typical Interpretations, which most of our late Christian Expositors are so full of upon all Occasions.”24

In order to demonstrate the literal meaning "without any recourse to Typical, Foreign and Mystical Expositions" ${ }^{25}$ Whiston postulated the corruption of the text by second-century Jews, whose intent, he insisted, was to confound Christianity. Just as the Athanasian Creed brought confusion and falsity to Christian notions of the father and the son, Jews had manipulated the text of the Bible to mislead its followers during the period of early Christianity. As Irven Resnick has shown, this accusation of Jewish textual corruption has always existed in Christendom, and gained strength and sophistication in the late twelfth and thirteenth centuries. ${ }^{26}$ Such accusations also flourished in Islam. Whiston was therefore weaving an old story into his text-critical work: a familiar anti-Judaism into new manuscript discoveries and analysis.

In his An Essay Towards Restoring the True Text of the Old Testament (1722) Whiston cites the talmudic principle of tiqqun sopherim as a starting point for his accusation against the Hebrew Masoretic Text, and its departures from other versions. ${ }^{27} \mathrm{He}$ faults the "later Jews" for altering the chronology and the messianic

23 The Literal Accomplishment of Scripture Prophecy. Being a Full Answer to a Late Discourse, of the Grounds and Reasons of the Christian Religion (London: J. Senex and W. Taylor, 1724).

24 William Whiston, The Accomplishment of Scripture Prophecies: Being Eight Sermons Preach'd at the Cathedral Church of St. Paul in the year MDCCVII (London, 1708), 13.

25 William Whiston, The Accomplishment of Scripture Prophecies: Being Eight Sermons Preach'd at the Cathedral Church of St. Paul in the year MDCCVII (London, 1708), 13.

26 Irven Resnick, "The Falsification of Scripture and Medieval Christian and Jewish Polemics," Medieval Encounters 2, no. 3 (1995), 344-80.

27 William Whiston, An Essay Towards Restoring the True Text of the Old Testament, and for Vindicating the Citations Made Thence in the New Testament (London: J. Senex, 1722), 221. 
prophecies of the Bible, to "stop the power of the Gospel." 28 In a nod to their own religious convictions, Whiston states that these rabbis were "lying for God," 29 but blames them unapologetically for all "modern difficulties" in interpretation. ${ }^{30} \mathrm{His}$ The Literal Accomplishment of Scripture Prophecies presents a detailed study of the prophecies in question, placing them side by side in two columns with their New Testament fulfillments. Marginal notes explain every corruption to the text made by Jews. Using the Septuagint, the Samaritan Pentateuch, and the Roman Psalter for comparison, Whiston notes where the Hebrew text misleads. Where no existing manuscript provides a prophecy to correlate with a New Testament citation, the Jews are blamed for the absence, as in this note on Matthew 2:23: "This Text is entirely wanting in all our Copies, Hebrew and Greek. Nor do there at present the least Footsteps of it remain, since the Jews corrupted their Copies." ${ }^{31}$ With the latest tools of biblical scholarship at hand, therefore, Whiston proposed to reconstruct the original text, which would, he believed, present a straightforward description of the messiah born in Bethlehem.

Most significant for our present purposes is Whiston's association of allegory with the contaminating nature of Jewish interpretation, which he makes in a supplement to An Essay Towards Restoring the True Text of the Old Testament. The supplement takes up the case of the Canticles, and argues against its inclusion in the canon. Whiston does not challenge the traditional attribution of authorship to King Solomon, but says that it was written late in Solomon's life when he was influenced by Egyptian ways and entrenched in idolatry. Any moral content that could be derived from Canticles would depend on a reading that was "entirely mystical and allegorical." 32 The literal sense alone is depraved, and as such has no place in holy Scripture. Whiston uses Canticles as an opportunity to declare allegory "that later Jewish Method of Interpretation," 33

28 William Whiston, An Essay Towards Restoring the True Text of the Old Testament, and for Vindicating the Citations Made Thence in the New Testament (London: J. Senex, 1722), 223.

29 William Whiston, An Essay Towards Restoring the True Text of the Old Testament, and for Vindicating the Citations Made Thence in the New Testament (London: J. Senex, 1722), 224.

30 William Whiston, An Essay Towards Restoring the True Text of the Old Testament, and for Vindicating the Citations Made Thence in the New Testament (London: J. Senex, 1722), 232.

31 Whiston, Literal Accomplishment, 4.

32 William Whiston, A Supplement to Mr. Whiston's Late Essay, Towards Restoring the True Text of the Old Testament: Proving, that the Canticles is Not a Sacred Book of the Old Testament; nor was Originally Esteemed as such, either by the Jewish or the Christian Church (London: J. Senex, 1723), 12.

33 William Whiston, A Supplement to Mr. Whiston's Late Essay, Towards Restoring the True Text of the Old Testament: Proving, that the Canticles is Not a Sacred Book of the Old Testament; nor was Originally Esteemed as such, either by the Jewish or the Christian Church (London: J. Senex, 1723), 41. 
pointing to Philo as the father of allegory and to Philo's Egyptian (that is, idolatrous), heritage. He argues that allegory takes a hold on biblical tradition only after the fall of Jerusalem, and is used by the earliest Christians only when they are engaged in debate with Jews. ${ }^{34}$ The inclusion of Canticles in the canon came in the second century, when allegory was in fashion and, importantly, at the same time the Jews were engaged in their textual corruptions, as Whiston's argument goes. ${ }^{35}$

Whiston had many critics but none elicited the spirited response, from Whiston and others, that freethinker Anthony Collins did with his work A Discourse of the Grounds and Reasons of the Christian Religion. ${ }^{36}$ Collins argued that rather than rescue the Old Testament for Christianity the man was undermining it. In his sardonic attack, Collins questioned the very notion that more reliable sources for the Old Testament could be identified or that if they could Whiston was the man for the job. He asserted that, in his words: “a Bible restor'd, according to Mr. Whiston's Theory, will be a mere Whistonian Bible, a Bible confounding and not containing the true Text of the Old Testament." ${ }^{37}$ Collins' Discourse pointed to the need for a radically different approach to Scripture, one found paradoxically in the heart of Judaism. For this Collins cited the theories of Dutch scholar William Surenhusius, whose legendary encounter with a wise rabbi led him to believe in the revelatory nature of the Mishnah and the legitimacy of Jewish methods for interpreting Scripture. The anonymous rabbi, who was

34 William Whiston, A Supplement to Mr. Whiston's Late Essay, Towards Restoring the True Text of the Old Testament: Proving, that the Canticles is Not a Sacred Book of the Old Testament; nor was Originally Esteemed as such, either by the Jewish or the Christian Church (London: J. Senex, 1723), 21.

35 More positive elements of Whiston's interaction with Judaism are brought out by Adam Shear. Whiston's Arianism made Jewish acceptance of Jesus as divine unnecessary for their salvation. And Jewish national restoration was seen by Whiston as an important precursor to, rather than result of, the second coming of Christ. Even more striking was Whiston's incorporation of mitzvot, kashrut, and the Saturday Sabbath into his notions of what a true Christian practice should look like. His "chimerical philosemitism," to borrow Shear's phrasing, was not unique, as Christians across Europe had long viewed the conversion of the Jews as integral to bringing on the messianic age. Whiston's distinctive contribution was his elaborate documentation of Jewish textual corruption, and the accompanying link between Jews and allegory. See Adam Shear, "William Whiston's Judeo-Christianity: Millenarianism and Christian Zionism in early enlightenment England," in Philosemitism in History, eds. Jonathan Karp and Adam Sutcliffe (New York: Cambridge University Press, 2011), 93-110.

36 Anthony Collins, A Discourse of the Grounds and Reasons of the Christian Religion (London: 1724).

37 Anthony Collins, A Discourse of the Grounds and Reasons of the Christian Religion (London: 1724), 255. 
described as: "well skill'd in the Talmud, the Cabbala, and the allegorical books of the Jews," ${ }^{38}$ was an astute interpreter of the New Testament as well as the Old. When presented with the problem of how the New Testament authors inaccurately cite Hebrew scriptures, the rabbi revealed the solution: he demonstrated that the New Testament is a mystical interpretation of the Old, properly interpreted only by the methods of Kabbalah. Collins surmises from his consideration of this account, that Paul, as well as the Gospel writers, must have been educated in the ways of Kabbalah, gaining the ability to interpret the mysteries of Scripture. ${ }^{39}$ Citing Surenhusius' encounter, Collins therefore concluded that "Christianity is the allegorical sense of the Old Testament, and is not improperly called mystical Judaism.”40

Collins' admiration for Jewish mystical hermeneutics is tinged with irony, and conflicting theories exist among contemporary historians and biographers on precisely how sarcastic Collins was being: on whether or not Collins' admiration for Surenhusius was genuine..$^{41}$ David Ruderman, for his part, argues for the seriousness of Collins' underlying purpose, even if it was cloaked in irony, and considers the possibility that Collins was offering a sincere response to Whiston's theories. As evidence, Ruderman points to both Collins' source, Michel de la Roche, and his followers, such as Edward Chandler, bishop of Coventry, who took the point very seriously indeed, as did Surenhusius' followers on the continent. Such men, steeped in Hebrew studies and Judaics already, were drawn to comparisons between New Testament and early rabbinic texts. De la Roche wrote that the New Testament authors "have done nothing in the present Case but what

38 Anthony Collins, A Discourse of the Grounds and Reasons of the Christian Religion (London: 1724), 55.

39 An interesting corollary to this idea developed several decades later, with Krishna Mohan Banerjea (1813-1885), a Bengali convert to Christianity. In his 1875 book The Arian Witness, he argues that the Vedas are closer to the spirit of Christianity than the Hebrew scriptures and contain the hidden mysteries of Christianity, including the anticipated coming of Christ. See R. S. Sugirtharajah, Asian Biblical Hermeneutics and Postcolonialism: Contesting the Interpretations (New York: Orbis Books, 1998), 4-5.

40 Collins, A Discourse, 92.

41 Scholars such as James O’Higgens, David Berman, Pascal Taranto, Hans Frei and David Ruderman each present a different Anthony Collins. Some view him as an atheist, others as a deist, still others as a committed Christian. Frei points to the fact that Collins was a disciple of John Locke as evidence of Collins' skepticism with regard to rabbinic methods. In Frei's view, Collins would have believed, as a follower of Locke, that the "lost rules governing nonliteral interpretation are completely arbitrary nonsense and the interpretation itself therefore nonsensical.” Frei, The Eclipse, 70. 
was practiced by the ancient Hebrew Theologers." 42 Even if Collins was wholly sarcastic, therefore, many of his readers were not.

Christianity faced unprecedented challenges in the eighteenth century, and the latest in historical and scientific methods of exegesis had not always served it well. In many instances, it had left behind a text that no longer cohered. New methods of interpretation were needed; the medieval reliance on allegorical reading was viewed by many as naïve and out of touch with advancements of modernity. Whiston's attempt at a scientific and literal reading of the Bible was the result of a crisis in Christian hermeneutics, and Collins' response exploited the difficulty inherent in such a project. That both men benefitted from their version of the "hermeneutical Jew" ${ }^{33}$ tells us more about their Christian context than it does about their contemporaries in the Jewish community. Before turning to a Jewish context with the work of Moses Mendelssohn, however, a brief look at the work of a Jewish convert to Christianity during this period further reveals the entanglement of biblical allegory and the Christian discourse of the Jew.

\title{
3 Johan Kemper: Commentaries of a Convert
}

In his commentary on the Gospel of Matthew, Me'irat einayim (1704), Hebrew lecturer at Uppsala University, Johan Kemper (1670-1716), makes the curious connection between the biblical image of the serpent and Jesus Christ, the Messiah. In commenting on Matthew 8:26, wherein Jesus commands the seas to calm, Kemper ties together Old Testament and New Testament imagery:

\begin{abstract}
Observe that Moses lifted his staff over the sea and divided it, and this staff is a remez of the Staff of mightiness, which is Jesus, as it is written: "The Lord will extend your mighty scepter" (Ps 110:2); and consequently that staff turned into a snake, because "snake" by means of gematria is equal to the Messiah, and therefore that staff swallowed up the snakes that the magicians made. ${ }^{44}$
\end{abstract}

42 From Michel de la Roche's Memoirs of Literature, as quoted in Ruderman, Connecting the Covenants, 72.

43 See Shear, "Whiston's Judeo-Christianity," 109.

44 Johan Kemper, Me'irat einayim, translated in Mats Eskhult, "Rabbi Kemper's Case for Christianity in his Matthew Commentary, with Reference to Exegesis," in Religious Polemics in Context: Papers Presented to the Second International Conference of the Leiden Institute for the Study of Religions, eds. Arie van der Kooij and Theo L. Hettema (Assen, The Netherlands: Royal Van Gorcum, 2004), 157. The full Latin translation of Kemper's commentary on Matthew 8:26, Illuminatio oculorum, can be found in Josef Eskhult, “Andreas Norrelius' Latin translation of Johan Kemper's Hebrew commentary on Matthew: Edited with introduction and philological commentary." PhD diss. (Uppsala University, 2007), 347-8. 
This association would not have been entirely lost on his Christian readers, who would have inherited typological comparisons between Jesus and Moses' staffturned-serpent in Exodus 4, Exodus 7, and Numbers 21. This instance in particular, however, betrayed Kemper's commentary as distinctively Sabbatian. While kabbalistic references to the "holy serpent" have their origins in thirteenth-century Spanish Kabbalah ${ }^{45}$ it became a central figure in the late seventeenth-century messianism of Shabbetai Zevi and his prophet, Nathan of Gaza. ${ }^{46}$ Kemper's reading is backed by the numerological equivalence between the Hebrew words for messiah and serpent - mashiah and nahash - both add up to 358 according to the system of gematria. Kemper's use of the term "dragon" in the same paragraph to refer to the serpent bears the mark of Nathan's Zoharic Treatise on the Dragons, and Shabbetai Zevi himself used the figure of the snake in his personal signature. ${ }^{47}$ As scholars such as Elliott Wolfson and Mats Eskhult have recently demonstrated, Kemper's commentaries and other writings present a man whose former messiah, a seventeenth-century imposter, came to be replaced by the first century Jesus. Other Sabbatian terms and concepts found in Kemper's commentary include his repeated use of the term "Holy King," his reference to the three parzufim, or faces, of the divine, ${ }^{48}$ and most importantly, his treatment of Jewish law with its simultaneous fulfillment and retraction, a theme to which I will return below. 49

How did such a commentary, written in Hebrew and then translated and published in Latin, come to be produced at the Swedish University? A scan of the scholarship on Kemper and his role at Uppsala reveals the recurrence of the term "philo-Semitism" by way of contextualization. The phrase has been problematized by today's historians of early modern Europe, ${ }^{50}$ especially given the missionizing intentions of the many efforts in this direction, but it nevertheless describes

45 The image of the holy serpent appears in The Treatise on the Left Emanation by R. Isaac b. Jacob Ha-Kohen and in Zohar III 119b.

46 Gershom Scholem, Sabbatai Sevi: The Mystical Messiah, trans. R. J. Zwi Werblowsky (Princeton University Press, 1976), 235, 309, 813.

47 Gershom Scholem, Sabbatai Sevi: The Mystical Messiah, trans. R. J. Zwi Werblowsky (Princeton University Press, 1976), 235.

48 Hans-Joachim Schoeps, Barocke Juden, Christen, Judenchristen (Bern: Francke Verlag, 1965), 60-7, trans. George Dole for Studia Swedenborgiana 7 (December 1990).

49 Elliot Wolfson, "Messianism in the Christian Kabbalah of Johann Kemper," in Millenarianism and Messianism in the Early Modern European Culture: Jewish Messianism in the Early Modern World, eds. Matt D. Goldish and Richard H. Popkin (New York: Springer, 2001), 153.

50 See, for instance, Sutcliffe, Judaism and Enlightenment, 6-11, and Eliane Glaser, Judaism without Jews: Philosemitism and Christian Polemic in Early Modern England (Basingstoke: Palgrave Macmillan, 2007). 
something of the fervor of Protestant Hebraism that characterized the period and the place. ${ }^{51}$ Like other European nations, Sweden experienced a wave of interest in Kabbalah and primitive Christianity due to a variety of influences including Pietism and Neoplatonism. King Carl XI encouraged scholarly investigation of Jewish texts, despite the complete absence of Jews from his kingdom, ${ }^{52}$ and the surge of dissertations on rabbinic topics in Sweden left "all other European countries far behind," as Hans-Joachim Schoeps writes..$^{53}$ Jewish commentaries, such as those by Maimonides, Abravanel, Ibn Ezra, and Rashi, were made available in university libraries and converted rabbis were sought for the teaching of Hebrew and rabbinics.

Kemper's autobiographical Unterthäniger bericht [“Humble Report”] tells the story of both his conversion from Judaism to Christianity and his migration from Kraków to Schweinfurt to Uppsala. Born Moses Aaron, he became fatherless as a young boy and as a consequence of the family's instability and his facility with learning, he found himself in the homes of rabbis and of Christians, educated in various religious contexts in rabbinic texts and in the Bible. As an adult, he was "seized by a heavy anxiety about the true sense of the prophecies," as biographer Josef Eskhult puts it, and was drawn to the messianic predictions that followed the apostasy of Shabbetai Zevi. ${ }^{54}$ Moses Aaron threw himself into the hope of a coming messianic age along with so many who looked to the pseudo-messiahs of the time. His profound disillusionment after the foretold date of September 5, 1695 came and went, led him to reconsider his understanding of Scripture. His relationships with Christian clergy members who had sought him out for Hebrew instruction were fortified in this crisis, and ultimately led him to his conversion and to Sweden where he fit the profile of an able Judaeus conversus to teach at Uppsala University.

Kemper's biblical commentary is of interest to scholars for several reasons. His blend of Christianity, the Zohar, rabbinic Judaism, and Sabbatianism, all in

51 The question of how to describe this particular iteration of Christian interest in things Jewish, whether to frame it positively or negatively, is not easily answered. Hans-Joachim Schoeps compares the relationship between philo-Semitism and anti-Semitism in the seventeenth century to "a sluggish canal and a broad torrent." Schoeps, Barocke Juden, 8, Dole Translation.

52 King Carl XI exemplifies the murkiness of Swedish philo-Semitism in his remarks to Laurentius Norrmanus, who was sent to Germany in search of a Jewish convert to teach at Uppsala, when he instructs Norrmanus to "find Jewish entrenchments and how to undermine them." See Eskhult, “Rabbi Kemper's Case,” 152.

53 Schoeps, Barocke Juden, 64, Dole translation.

54 Eskhult, “Andreas Norrelius' Latin,” 316. It wasn’t Zevi’s apostasy that caused Kemper's ultimate disillusionment, but the false prophecy of the kabbalist Zadok of Vilna, who predicted the Messiah would come in 1695, 29 years after Zevi converted to Islam. 
the associative style of midrash and all in Hebrew, tells not only his personal story but the story of an age. He was of course held up by his students as a model of the marriage of ancient Jewish sagacity and true Christian faith, or in the words of his Latin translator Anders Norrelius, a "Rabbi moistened with the waters of the salvation-bringing Baptism and of the sound spring of wisdom." 55 To contemporary historians, his commentary stands at the intersection of ideas and movements characteristic of the early eighteenth century, and can tell us a great deal about a particular clash of culture and thought that led to new ways of thinking as the century progressed.

Kemper represents the ambivalence of Christian kabbalists of his time in his attempt to both "transcend Judaism and extinguish it," to use Sutcliffe's terms. ${ }^{56}$ The effort to simultaneously venerate and erase Judaism, however, is magnified in Kemper's work, especially in regard to legal material. In considering how Kemper is unique among the Christian kabbalists of early modernity, Elliot Wolfson points to his need "to preserve the nomian framework of the Kabbalah even as he sought to undermine that framework by proving the truths of Christianity on the basis of the traditional texts." 57 This "hypernomianism," is fed by Kemper's rabbinic background and his effort to extend the law beyond the boundaries of Judaism. Accordingly, the law becomes even more relevant in a Christian context. And while a spiritualized explanation of the laws of circumcision, for instance, does have other Christian corollaries, his insistence that the close reading of kabbalistic texts is key to a true Christian understanding of the law is distinctive. For instance, Kemper's Trinitarian interpretation of the customary kabbalistic prayer "for the sake of the unification of the blessed holy One and his presence" is backed by an understanding of the nature and relationship between the divine attributes, the parzufim..$^{58}$ His formula suggests that Jews everywhere, as Wolfson notes, unwittingly affirm the trinity whenever they recite it. ${ }^{59}$

Kemper's syncretism is nowhere more evident than in his commentary on the Zohar, Beriah ha-tikhon, where he insists that the Gospels are the true Oral Torah. ${ }^{60}$ The Word made flesh is the spoken word, the Oral Torah, the true interpretation of the Hebrew scriptures:

55 Anders Norrelius Prolegomena, translated in Eskhult “Andreas Norrelius' Latin,” 315.

56 Sutcliffe, Judaism and Enlightenment, 154.

57 Wolfson, "Messianism," 141.

58 Kemper, Maqqal Ya'aqov, fol. 15b (www.alvin-portal.org); see also Wolfson, "Messianism," 181, fn. 185.

59 Wolfson, “Messianism," 159.

60 Johan Kemper, Beriah ha-Tikhon, fols. 201b-202a (www.alvin-portal.org), as translated in Wolfson, "Messianism," 150. 
This Torah was spoken orally by the Messiah to all the patriarchs and to the true prophets, and it was as clear as the sun, but they were commanded to write it in a hidden way that would have to be explained orally to the masses, and especially the teaching of the Gospel that the holy mouth spoke to you. This secret may be revealed, but to others it must be by way of parable that needs a commentary, and this is the true, just and correct Oral Torah. ${ }^{61}$

This does not negate the wisdom of the Talmudic sages; again, Kemper draws on his rabbinic training in his post-conversion commentaries. The sages, he insists, knew the truth of the Gospels, and encoded it in their own commentaries. The Talmud, like the Torah, has layers or senses, and when properly interpreted bears testimony of Christ: for "[the] masters of the Talmud were cunning, and all of the words that they uttered were parables and riddles, and words that draw the heart." ${ }^{2}$ Rashi, too, knew this truth and encoded it. For instance, Kemper incorporates Rashi's interpretation of Genesis 28 into his own interpretation of Matthew 21:42 (itself an interpretation of Psalms 118:22). Employing the kabbalistic methods of sod, remez, and peshat, Kemper demonstrates the levels upon levels of tradition and text that need uncovering for the truth of Christianity to be revealed. On the stone that the builders rejected, he writes:

This is a matter of sod, namely he took the stone, (Gen 28:11) which (in turn) is a remez of the Messiah, because Jacob placed his head on the stone of justice, since he believed in the Messiah [... Observe, it is not the literal sense that Rashi refers to, when he, drawing from the Talmud, says that Jacob took more than one stone, when he made a kind of gutter, etc., and the Holy, blessed be he, made these into one. The secret is that Jacob took three stones, a hint of the Trinity, and they became one, that is Unity. ${ }^{63}$

That Rashi expands on the biblical text, adding to it the idea that many stones were needed to create a ditch for Jacob's head, and that God then made these stones one, is a hint to the reader of a Triune God. Therefore, according to Kemper, the Trinitarian truth of the Torah was known to all of its Jewish authors and commentators, but is lost on the typical Jewish reader. The general population of Jews are in the dark when they read and study their texts, but nevertheless preserve a truth they cannot perceive. Satan himself is to blame for the Jews' forgetfulness: for their inability to recall the true meaning of Scripture:

61 Johan Kemper, Avodat ha-Qodesh, fol. 134a (www.alvin-portal.org), as translated in Wolfson, "Messianism," 151.

62 Johan Kemper, Beriah ha-Tikon, fol. 160a (www.alvin-portal.org), as translated in Wolfson, "Messianism," 167.

63 Johan Kemper, Me'irat einayim, as translated in Eskhult, M. "Rabbi Kemper’s Case," 157. The Latin translation of Kemper's commentary on Matthew 21:42 can be found in Eskhult "Andreas Norrelius' Latin Translation," 384-5. 
He who has a brain in his head will conclude that the patriarchs point to the Trinity, and Satan assisted them in this matter, until the point that the wisdom of the Kabbalah was also lost. But know that even today they have very ancient and just customs that instruct about the Trinity, but they cover their faces with a mask. ${ }^{64}$

The Jews are rebuked for hiding their faces with a mask, even as the three faces of God are concealed in holy texts. A holy mystery contends with a wicked disguise.

As we see in the other eighteenth-century commentaries in this study, Judaism is associated with allegory. Both the Torah and its commentaries contain hidden secrets that the sages preserve. Christianity is associated with the uncovering of secrets, the bringing out into the open. As someone who inhabited both worlds, however, Kemper divides the Jews into two camps: the sages who knew the truth of their encoding, and the reading public who miss the point. An ignorant literalism is associated with Jews while an enlightened literalism is attached to Christians and to the New Testament as Oral Torah. ${ }^{65}$

Kemper read Jesus into every story of the Hebrew Bible and into every Jewish custom using the Hebrew term for type: mashal. Jesus is the shekhinah; Jesus is the afikoman, the mezuzah, the fiftieth day after Pesah; Jesus is Torah, Shabbat, Metatron; Jesus is Abraham, Isaac, Jacob, Moses and Job. He is the ark, the stone, and the temple: "the goal, archetype, end and fulfilment of all prophecies, holy prototypes and prefigurations." ${ }^{\circ 6}$ Again, there is certainly precedence for such a hermeneutic in Christianity, regarding the Bible at least, and Kemper's conversion can explain much of his interpretation, even if the format is in an associative, midrashic style. However, we can also trace such an interpretive fixation through Sabbatianism. Nathan of Gaza borrowed the methods of the marrano Solomon Molko, who introduced Christian allegories into his commentaries. Nathan used Molko's interpretations and substituted his own messiah when interpreting Job, for instance, as an allegory for Shabbetai Zevi. ${ }^{67}$ About which sources influenced Kemper's own biblical interpretation we can only speculate. But it certainly bears the markings of a tortuous genealogy, one with forays into Jewish contexts, Christian contexts, and contexts whose Jewish and Christian

64 Johan Kemper, Maqqal Ya'aqov, fol. 49b (www.alvin-portal.org), as translated in Wolfson, "Messianism," 161.

65 This resonates with medieval distinctions between the Christian literal sense and the Jewish carnal sense. See Klepper, "Literal vs. Carnal: George of Siena’s Christian Reading of Jewish Exegesis," in Jewish Biblical Interpretation and Cultural Exchange: Comparative Exegesis in Context, eds. Natalie Dohrmann and David Stern (Philadelphia: University of Pennsylvania Press, 2008), 196-213.

66 As described by Kemper biographer Anders Norrelius in his Prolegomena, translated in Eskhult “Andreas Norrelius' Latin,” 319.

67 Scholem, Sabbatai Sevi, 309. 
strands are indistinguishable. His personal history and his life's work tell the story of religious nomadism, and allegory is the vehicle for the passage of ideas back and forth across religious boarders.

\section{Moses Mendelssohn: A Theory of Language}

The question of the multivocality of the biblical text was revisited by eighteenthcentury Jewish intellectuals as well, responding to challenges in many ways similar to those facing Christendom, but also in ways unique to Jewish contexts. Such challenges included, but were not limited to, forms of biblical criticism initiated by Spinoza in the seventeenth century, and challenges to the veracity of the Masoretic Text, such as those illustrated above in the work of William Whiston. Jewish biblical scholars, like their Christian counterparts, struggled to demonstrate the reasonableness of traditional modes of interpretation in an Enlightenment context, but Jews had the added challenge of contending with Christian discursive uses of rabbinic exegesis, such as those sampled above. We will end this brief study of biblical allegory and Jewish-Christian relations in the eighteenth century, with the work of the Jewish German philosopher Moses Mendelssohn (1729-1786). Mendelssohn's notions about the plurality of meanings in human language and in revealed texts mirrored his views on the possible coexistence of diverse religious communities, as we will see.

In the introduction to his Hebrew language commentary on the book of Ecclesiastes, Mendelssohn defended the medieval model of four methods of interpretation, with an appeal to logic:

As is well known, there are four ways to elucidate our holy Torah, peshat, derash, remez, and sod. They are all words of the living God and are all correct. This neither contradicts the ways of the intellect and logic, nor is strange and astonishing to human understanding, as I will elucidate with the help of the Eternal, may He be blessed. ${ }^{68}$

This statement is a defense of an old hermeneutical system for a new age. Written in Hebrew, his commentary appealed to a Jewish audience, but Mendelssohn made use of systems of thought developed in his German-language philosophical

68 Moses Mendelssohn, "Biur Megilat Kohelet," in Gesammelte Schriften, Jubiläumsausgabe, eds. Alexander Altmann, Eva J. Engel, Michael Brocke and Daniel Krochmalnik (Stuttgart-Bad Cannstatt, Germany: F. Frommann, 1971-), as translated in Michah Gottlieb, ed., Moses Mendelssohn: Writings on Judaism, Christianity and the Bible (Lebanon, New Hampshire: Brandeis University Press, 2011), 176. 
work throughout his commentary, and responded to theoretical challenges facing biblical religion more broadly. ${ }^{69}$

The challenge for Mendelssohn and his followers, the Maskilim, was to engage the field of modern biblical scholarship as it was developing in Germany, while not compromising on the authority of medieval Jewish sources, which they understood to be the key to biblical interpretation. Mendelssohn saw himself as uniquely suited to bridge the two worlds of Jewish tradition and enlightenment scholarship. At once committed to rabbinic authority and to Hebrew language study and literary criticism, Mendelssohn's middle way involved a dedicated engagement with both ways of knowing. This is most evident in his publication of a German translation of the Pentateuch with commentary, Sefer netivot hashalom, commonly referred to as the Bi'ur, a collaborative effort he spearheaded after beginning a translation for his son's education. Mendelssohn's attention to grammar and philology reflected the interests of modern biblical scholarship, as did his consideration of various manuscripts of the biblical text. The introduction and much of the commentary addressed the concerns of the modern reader, while the commentary drew heavily on interpretations from rabbinic exegetes, especially Ibn Ezra and Rashi. In all of this, Mendelssohn conveyed the message that Judaism was not only capable of engaging in a sophisticated rendering of the biblical text, but that it was uniquely suited to do so.

Mendelssohn's commentaries therefore expanded on the plain sense of the text, or the peshat, and at the same time articulated a general theory of language that allowed for layers of meaning. All language, he argued, written or spoken, can be interpreted in multiple ways. Inspired in part by Maimonides, he developed the concepts of the primary and secondary meanings of language. Language uses both conventional and spontaneous signs; it carries a generally intended meaning, as well as subtle nuances that belie levels of intentionality on the part of the speaker. In this, it is like other aspects of the natural world. Limbs, and other body parts perform various functions, as do the elements of nature. "For example, He created the nose for smelling, for breathing, for expelling excess moisture, and for enhancing facial beauty [....] Therefore it is not implausible that the [Supreme] Wisdom should have many different intentions in one utterance, and that they are all true."70 If, applying common sense, we

69 For a full analysis of Mendelssohn's contribution to biblical translation and Jewish integration, particularly the political implications of translation between Yiddish, Hebrew and German, see Naomi Seidman, Faithful Renderings: Jewish-Christian Difference and the Politics of Translation (University of Chicago Press, 2010), ch. 4.

70 Moses Mendelssohn, “Biur Megilat Kohelet,” in Gesammelte Schriften, Jubiläumsausgabe, as translated by Gottlieb in Moses Mendelssohn, 181-1. 
can understand the levels of meaning in everyday speech and other natural phenomenon, Mendelssohn argued, how much more so with a sacred text? "On this basis, you will understand how it is possible to elucidate in many ways - through derash, remez, and sod - everything that is said through prophecy or the holy spirit, and how they are all correct along with peshat, which is the most necessary of all," he maintained. ${ }^{71}$ His understanding of the conventional and spontaneous aspects of speech was thereby applied to traditional rabbinic hermeneutics.

In Mendelssohn's conception, the peshat, the plain sense, can be gleaned from a loose reading of the text, by paying attention to the general meaning, with little concern for the particularities of word choice and rhetoric. On the other hand, a nonliteral meaning relies on every detail. Just as one might analyze the specific words, their ordering, or the tone in which they are delivered, of another person's speech in order to read the implicit connotations of what they are saying, so too rabbinic tradition reads levels of meaning into every nuance of the text. The derash, or the secondary intention of the text, requires the isolation of, and elucidation on, specific terms: "Therefore you will see that when Rashi, the light of the exile, may his memory be for a blessing, follows derash in his commentary on the Torah, the Prophets, and the Writings, he will at times elucidate each verse on the basis of some isolated feature, detached from neighboring verses, leaving aside their context and continuity."72

In the introduction to Sefer netivot ha-shalom, Mendelssohn meditates on the problem of literalism and translation. It is a problem of utmost concern, as there are instances when a literal translation can mislead, and even make a liar out of the text. ${ }^{73}$ He proposes a methodology to guide his own translations as a way to avoid this grave pitfall: where the peshat and the derash agree, he translates according to the peshat; where they diverge, he translates according to the derash. Using the commentaries of Rashi, Rashbam, Ibn Ezra, Nahmanides, and Radak, as guides, Mendelssohn considers the primary and secondary meanings of the passages he translates and makes word choices accordingly, to best guide his readers. In every instance where the peshat can carry multiple meanings, it must

71 Moses Mendelssohn, "Biur Megilat Kohelet," in Gesammelte Schriften, Jubiläumsausgabe, as translated by Gottlieb in Moses Mendelssohn, 181.

72 Moses Mendelssohn, "Biur Megilat Kohelet," in Gesammelte Schriften, Jubiläumsausgabe, as translated by Gottlieb in Moses Mendelssohn, 180.

73 Moses Mendelssohn, "Or Lintivah" ["Light for the Path," the introduction to Sefer netivot ha-shalom], in Gesammelte Schriften, Jubiläumsausgabe as translated in Gottleib, Moses Mendelssohn, 192. 
be preserved: "It is the way of one who has mastered a language to sometimes have different intentions in one statement."74

His exegesis, as well, was informed by an understanding of the text as speaking to more than one level of meaning simultaneously. An example from his commentary on Genesis 2 demonstrates an instance where Scripture tells the true story of real people in history, but also instructs the reader on the level of personal morality and predicts future states of the human race:

The entire account of creation, as well as all that scripture recounts regarding what happened to Adam, Eve, Cain, and Abel, is all true and reliable without doubt: what actually happened to these individuals is just as [scripture] recounts it. In addition, however, these stories contain an allusion to and model for what will happen to the entire human species in general. What happened to Adam and his children in particular is what happens to the entire species in general. For this reason, scripture describes at length the details of their [lives], on the basis of which a wise individual will understand all that happens to human beings, from the time they were created to the end of all the generations. ${ }^{75}$

Mendelssohn goes on to explain how Adam's story reflects the story of all humans, who must achieve balance between two complimentary faculties: comprehension and desire. When Adam ate of the tree of knowledge of good and evil, he became like the angels. But an angelic balance of these faculties is not appropriate for humans: desire overtook his comprehension. Each individual's character is determined by the ability to bring the two faculties back into a harmonious relationship. And he notes, perhaps in an attempt to distinguish his from Christian typological interpretations, different levels of meaning do not supersede one another. One level does not follow or displace another, but they exist simultaneously, available to the reader to make use of in whatever order or combination benefits him or her at a given moment.

Key to Mendelssohn's understanding of biblical texts are his views on the role of the Hebrew language and the Jewish people in history. Following the work of William Warburton, Mendelssohn became interested in the relationship between Egyptian hieroglyphics and Hebrew script and the religious implications of such a connection. ${ }^{76}$ In his Jerusalem, he posits that the Hebrew language was

74 Moses Mendelssohn, "Or Lintivah" ["Light for the Path," the introduction to Sefer netivot ha-shalom], in Gesammelte Schriften, Jubiläumsausgabe, as translated in Gottleib, Moses Mendelssohn, 199.

75 Moses Mendelssohn, Sefer Netivot Hashalom, in Gesammelte Schriften, Jubiläumsausgabe, "Commentary on Genesis 2:9," as translated in Gottlieb, Moses Mendelssohn, 208.

76 On the interest in Egyptology and hieroglyphics in the seventeenth and eighteenth centuries, including the work of Mendelssohn's interlocutor Warburton, see Jan Assmann, Moses the Egyptian: The Memory of Egypt in Western Monotheism (Cambridge: Harvard University Press, 1997), 55-143. 
the bridge between a pictographic system and an alphabetical system, each of which have their advantages and disadvantages. It solved the problem of idolatry, inherent in hieroglyphics, but mediated more of a direct connection than a fully conventional system by maintaining some resemblances. The Hebrew letter bet looks like a bayit, the gimel like a gamal, and so on. ${ }^{77}$ Hebrew is therefore a kind of archeological artifact documenting the shift in human knowledge that abstraction made possible. Mendelssohn believed abstract signs are necessary for the development of human reason, as they contain and communicate knowledge while encouraging the mind to look for meaning beyond a simple picture: "Wise Providence has placed within the soul's immediate reach a means which it can use at all times. It attaches, either by a natural or an arbitrary association of ideas, the abstracted characteristic to a perceptible sign which, as often as its impression is renewed, at once recalls and illuminates this characteristic, pure and unalloyed." "78 Hebrew, which Mendelssohn believed to be "the source of all other known ways of writing," "79 led the way in making units of writing more abstract and human knowledge more refined. However, the threat of idolatry still remained.

In Jerusalem, Mendelssohn postulates that even text that is made abstract, avoiding the pitfalls of hieroglyphics, can become an idol. Anything that is fixed in time and space can become the object of misdirected devotion. Even the Pythagoreans, who attempted to avoid idolatry by seeking the divine in numbers alone, eventually failed, and put mathematics before God. This is why, according to tradition, Moses was permitted to write down only the bare minimum of the revelation he received; the rest was transmitted orally. Furthermore, the revelation that was committed to writing was primarily instruction for "ceremonial law" - a living script that could adapt to the unique needs and customs of every generation. Speech (Oral Torah) and action (fulfillment of the law) are superior symbols due to their flexibility and transparency. As Mendelssohn scholar Gideon Freudenthal writes: "Mendelssohn's idea is this: a good symbol is 'transparent.' We look 'through' it to what it stands for. A good symbol does not itself attract

77 Moses Mendelssohn, Jerusalem: Or on Religious Power and Judaism, trans. Allan Arkush (Lebanon, New Hampshire: Brandeis University Press, 1983), 110n. See also Gideon Freudenthal, No Religion without Idolatry: Mendelssohn's Jewish Enlightenment (Notre Dame: University of Notre Dame, 2012), 105-34.

78 Gideon Freudenthal, No Religion without Idolatry: Mendelssohn's Jewish Enlightenment (Notre Dame: University of Notre Dame, 2012), 105.

79 Moses Mendelssohn, Jerusalem: Or on Religious Power and Judaism, trans. Allan Arkush (Lebanon, NH: Brandeis University Press, 1983), 105. 
attention, is often not 'seen' at all." 80 The peshat of the Torah is revelatory to the extent that it points to a holy expression in words and action.

Mendelssohn's assertion that ceremonial law is the primary emphasis of the Torah countered the popular accusation that Jewish customs were backwards and outdated. Here we have a description of Jewish law and ceremony as a living connection to God. Mendelssohn viewed Jewish ritual as a particular manifestation of revelation in signs, but it is by no means universal or absolute. It is its very particularity that becomes a model for other religions, other nations, whose knowledge of revelation may be quite different: not better or worse, but necessarily different.

It is his reformulation of the relationship between the universal and the particular, and the role that divine revelation plays in this relationship, that will take us finally to Mendelssohn's most radical departure from the Christian philosophers of his day: the particularity of the Bible itself. In his Jerusalem, Mendelssohn asserts that the contents of the Bible, even as divine revelation, constitute historical truth, given to a particular community for a particular purpose. The contents do not describe universal mechanisms of salvation, but rather a path prepared for a given community leading away from idolatrous forms of religious expression. Such a line of reasoning challenges several fundamentals of Christianity: the nature of Scripture, the role of faith, and the promise of salvation through Christ. However, Mendelssohn's aim was not to weaken Christian truth claims, but to establish a philosophical framework for the flourishing of religious pluralism. A given community can hold fast to its version of historical truth as divine revelation without imposing this truth on those of other traditions. The multivocality in the Bible itself mirrored the possibility of a religiously diverse society.

In many ways, Mendelssohn's views on the particularity of written revelation were made possible by Spinoza's influential and iconoclastic Theologico-Political Treatise (1670), which provided a philosophical endorsement for historical criticism of the Bible, and inspired such sentiments as Gotthold Lessing's oft quoted statement: "The letter is not the spirit and the Bible is not religion. Hence, objections to the letter and to the Bible are not likewise objections to the spirit and to religion." ${ }^{81}$ At the same time, Mendelssohn's body of work also provided a

80 Gideon Freudenthal, No Religion without Idolatry: Mendelssohn's Jewish Enlightenment (Notre Dame, IN: University of Notre Dame Press, 2012), 107.

81 Gotthold Ephraim Lessing, "Editorial Commentary on the 'Fragments' of Reimarus, 1777," in Lessing: Philosophical and Theological Writings, ed. and trans. Hugh Barr Nisbet (Cambridge: Cambridge University Press, 2005), 63. On Spinoza's influence on Lessing and Mendelssohn see Allan Arkush. Moses Mendelssohn and the Enlightenment (Albany, State University of New York Press, 1994), ch. 5. 
defense of rabbinic truth claims and rabbinic methods, backed by medieval-style arguments from tradition and from the purported observations of Jews present with Moses at Mount Sinai..$^{82}$ His work walked the line between the thought patterns of the Middle Ages and those of modernity. As such, it drove a vision for pluralism, where Jew and Christian, traditionalist and critic can occupy the same thought space, even if it also provided plenty to object to from the perspectives of both orthodoxy and secularism. His last lines, "Love truth! Love Peace" are taken from a quotation from the eighth chapter of Zechariah, where Jews bring together the nations of the world..$^{83}$ It is difficult to see this utopian vision as anything other than eschatological. But Mendelssohn's Jerusalem does not herald the messianic age. It points to the realizable harmony between citizens of different faith traditions, and suggests that Germany's Jewish minority, rather than a mere remnant of a forgotten past, might have something to contribute to the health of the state.

It is not always wise to simplify a vast and varied set of writings, such as Mendelssohn's, into a convenient summary. For our purposes, however, a few key points are worth reviewing. Mendelssohn's contributions include the following points. All language carries multiple meanings. The Bible presents multiple meanings through signs. These meanings are carried via the subtleties of the written text, even in the shape of the letters, and rabbinic tradition holds the key to unlocking these meanings. The Hebrew language provided a pathway for the advancement for human understanding through abstraction (away from idolatry). As a technology it was providential, but its truth is not universal. Text is revelatory to the extent that it guides the religious practice of its reader. The Torah is holy to the extent that it sanctifies the ceremonial life of Jews, who, by participating in this particular lived interpretation of their texts, can be a model for other communities. Mendelssohn, thereby recast Jewish allegorizing in light of the political, historical, and theological concerns of his day and for the sake of Jewish integration. His general theory of language, that all language necessarily carries multiple meanings and requires interpretation, allowed him to mine rabbinic commentaries for treasures of meaning that could connect Jewish readers to their tradition. Furthermore, his assertion that the text of the Bible, as language, could mean more than one thing, reflected a political affirmation that communities, diverse even in their truth claims, can live together amicably.

82 See Arkush, Moses Mendelssohn, 168-170.

83 Zechariah 8:19. 


\section{Conclusion}

We have, here, briefly considered three commentators that demonstrate something of the nuances of eighteenth-century attitudes towards biblical allegory. On the one hand, the hunger for rational, systematic, universal truth that had been building since medieval times produced the Enlightenment palate for language that was simple, clear and meant only what it appeared to mean. On the other hand, readers of the Bible were confronted anew by discoveries, historical, linguistic and geological in nature, which made the plain sense of the text nearly impossible to accept in places. Add to this, shifting social, religious, and political contexts that further entangled Jews and Christians, even as efforts were made to fortify the boundaries that divided them. Each of the authors discussed above reveals something of the panorama produced by these opposing landscapes. In the name of science, Whiston attempted to interpret the entire Bible according to its plain sense and without recourse to allegory, but ironically, he believed the plain sense to have been corrupted beyond recognition by the Jews of antiquity. Kemper's approach, on the contrary, read hidden meaning into every biblical account, and drew on his extensive rabbinic and kabbalistic learning even in his Christological interpretations. He too, however, blamed the Jews for every misreading, for misunderstanding their own encoded language. Mendelssohn's approach attempted to preserve the Bible's multivocality, but insisted on the particularity of its symbols. The Jews understood very well their allegories, he argued, but the allegories themselves are not universal, nor can they be understood universally. These three cases illustrate reformulations of biblical allegory characteristic of their age as well as ways religious identity and Jewish-Christian relations continued to shape biblical hermeneutics into modernity.

Sutcliffe writes that for certain Enlightenment thinkers "Judaism was powerfully associated both with obstinate particularism and with utopian universalism." ${ }^{84}$ These paradoxical perceptions of Jewish difference are perhaps reflected in Enlightenment approaches to language as well. The appeal to universal principles in Scripture is more cumbersome when the interpretation of a text is bound to the particularities of the letter. The irony of the Bible in the eighteenth century is that the preference for the plain sense is what reveals its deficiencies. Each of the exegetes considered here found their own way through the hermeneutical challenges of their time by marrying multivocality and Jewish identity, in one way or another. This is a surprising turn, given the history of the Christian

84 Sutcliffe, Judaism and Enlightenment, 164. 
discourse of Jewish literalism, one that sheds further light on the thorny relationship between religious diversity and biblical exegesis.

\section{Works Cited}

Arkush, Allan. 1994. Moses Mendelssohn and the Enlightenment. Albany: State University of New York Press.

Assmann, Jan. 1997. Moses the Egyptian: The Memory of Egypt in Western Monotheism. Cambridge: Harvard University Press.

Buchwald, Jed Z., and Mordechai Feingold. 2013. Newton and the Origin of Civilization. Princeton: Princeton University Press.

Burnett, Stephen G. 2012. Christian Hebraism in the Reformation Era (1500-1660): Authors, Books, and the Transmission of Jewish Learning. Boston: Brill.

Colie, Rosalie L. 1963. "Spinoza in England, 1665-1730." Proceedings of the American Philosophical Society 107 (3): 183-219.

Collins, Anthony. 1724. A Discourse of the Grounds and Reasons of the Christian Religion. London.

Cowper, William. 1780. "God Moves in a Mysterious Way." In John Newton, Twenty-six Letters on Religious Subjects to Which Are Added Hymns, 252. Dublin: W. Gilbert.

Dwek, Yaacob. 2011. The Scandal of Kabbalah. Princeton: Princeton University Press.

Eskhult, Mats. 2004. "Rabbi Kemper's Case for Christianity in his Matthew Commentary, with Reference to Exegesis." In Religious Polemics in Context: Papers Presented to the Second International Conference of the Leiden Institute for the Study of Religions, edited by Arie van der Kooij and Theo L. Hettema, 148-164. Assen, The Netherlands: Royal Van Gorcum.

Eskhult, Josef. 2007. "Andreas Norrelius' Latin Translation of Johan Kemper’s Hebrew Commentary on Matthew: Edited with Introduction and Philological Commentary." PhD diss., Uppsala University.

Force, James. 1985. William Whiston, Honest Newtonian. Cambridge: Cambridge University Press.

Frei, Hans W. 1974. The Eclipse of Biblical Narrative: A Study in Eighteenth and Nineteenth Century Hermeneutics. New Haven: Yale University Press.

Freudenthal, Gideon. 2012. No Religion without Idolatry: Mendelssohn's Jewish Enlightenment. Notre Dame, IN: University of Notre Dame Press.

Glaser, Eliane. 2007. Judaism without Jews: Philosemitism and Christian Polemic in Early Modern England. Basingstoke: Palgrave Macmillan.

Harrison, Peter. 1998. The Bible, Protestantism, and the Rise of Natural Science. Cambridge: Cambridge University Press.

Jakapi, Roomet. 2005. "William Whiston, the Universal Deluge, and a Terrible Spectacle." Folklore: Electronic Journal 31: 7-14.

Kemper, Johann. 2007. Illuminatio Oculorum. Latin translation of Me'irat einayim by Andreas Norrelius, in “'Andreas Norrelius' Latin translation of Johan Kemper's Hebrew commentary on Matthew: Edited with introduction and philological commentary," by Josef Eskhult, 325-413. PhD diss., Uppsala University.

Kemper, Johann. Beriah ha-Tikon, MS Uppsala Heb 25. www.alvin-portal.org. 
Kemper, Johann. Matteh Moshe o Maqqel Ya'acov, MS Uppsala Heb 24. www.alvin-portal.org. Kemper, Johann. Karse ha-mishkan, 'Avodat ha-ḳodesh, Leket he-'ani, MS Uppsala Heb 26. www.alvin-portal.org.

Klepper, Deeana. 2007. The Insight of Unbelievers: Nicholas of Lyra and Christian Reading of Jewish Text in the Later Middle Ages. Philadelphia: University of Pennsylvania Press.

Klepper, Deeana. 2008. “Literal versus Carnal: George of Siena's Christian Reading of Jewish Exegesis." In Jewish Biblical Interpretation and Cultural Exchange: Comparative Exegesis in Context, edited by Natalie Dohrmann and David Stern, 196-213. Philadelphia: University of Pennsylvania Press.

Legaspi, Michael C. 2010. The Death of Scripture and the Rise of Biblical Studies. Oxford University Press on Demand.

Lessing, Gotthold Ephraim. 2005. “Editorial Commentary on the 'Fragments' of Reimarus, 1777." In Lessing: Philosophical and Theological Writings, edited by and trans. Hugh Barr Nisbet. Cambridge: Cambridge University Press.

Mendelssohn, Moses. 1971-. Gesammelte Schriften, Jubiläumsausgabe, edited by Alexander Altmann, Eva J. Engel, Michael Brocke and Daniel Krochmalnik. Stuttgart-Bad Cannstatt, Germany: F. Frommann.

Mendelssohn, Moses. 1983. Jerusalem: Or on Religious Power and Judaism, trans. Allan Arkush. Lebanon, New Hampshire: Brandeis University Press.

Mendelssohn, Moses. 2011. Moses Mendelssohn: Writings on Judaism, Christianity, and the Bible, edited by Michah Gottlieb, trans. Curtis Bowman, Elias Sacks, and Allan Arkush. Lebanon, New Hampshire: Brandeis University Press.

Ocker, Christopher. 2002. Biblical Poetics before Humanism and Reformation. Cambridge University Press.

Poole, William. 2010. The World Makers: Scientists of the Restoration and the Search for the Origins of the Earth. Oxfordshire, UK: International Academic Publishers.

Resnick, Irven. 1995. "The Falsification of Scripture and Medieval Christian and Jewish Polemics." Medieval Encounters 2 (3): 344-380.

Ruderman, David B. 2007. Connecting the Covenants: Judaism and the Search for Christian Identity in Eighteenth-Century England. Philadelphia: University of Pennsylvania Press.

Schoeps, Hans-Joachim. 1990. Barocke Juden, Christen, Judenchristen. Bern: Francke Verlag, 1965, trans. (of excerpts) George Dole, in "Philosemitism in the Seventeen Century." Studia Swedenborgiana 7: 5-17.

Scholem, Gershom Gerhard. 1976. Sabbatai Sevi: The Mystical Messiah, trans. R. J. Zwi Werblowsky. Princeton University Press.

Seidman, Naomi. 2010. Faithful Renderings: Jewish-Christian Difference and the Politics of Translation. University of Chicago Press.

Shear, Adam. 2011. “William Whiston's Judeo-Christianity: Millenarianism and Christian Zionism in Early Enlightenment England." In Philosemitism in History, edited by Jonathan Karp and Adam Sutcliffe, 93-110. New York: Cambridge University Press.

Sheehan, Jonathan. 2005. The Enlightenment Bible: Translation, Scholarship, Culture. Princeton: Princeton University Press.

Smalley, Beryl. 1983. The Study of the Bible in the Middle Ages. 3rd ed. Oxford: Basil Blackwell. Snobelen, Stephen D. 2001. “'God of Gods, and Lord of Lords:' The Theology of Isaac Newton's General Scholium to the Principia." Osiris 16: 169-208.

Stroumsa, Guy. 2010. A New Science: The Discovery of Religion in the Age of Reason. Cambridge, MA: Harvard University Press. 
Sugirtharajah, R. S. 1998. Asian Biblical Hermeneutics and Postcolonialism: Contesting the Interpretations. New York: Orbis Books.

Sutcliffe, Adam. 2003. Judaism and Enlightenment. Cambridge: Cambridge University Press. Toland, John. 1696. Christianity not Mysterious. London: Samuel Buckley.

Whiston, William. 1708. The Accomplishment of Scripture Prophecies: Being Eight Sermons Preach'd at the Cathedral Church of St. Paul in the year MDCCVII. London.

Whiston, William. 1717. Astronomical Principles of Religion, Natural and Reveal'd: In Nine Parts. London: J. Senex and W. Taylor.

Whiston, William. 1722. An Essay Towards Restoring the True Text of the Old Testament, and for Vindicating the Citations Made Thence in the New Testament. London: J. Senex.

Whiston, William. 1723. A Supplement to Mr. Whiston's Late Essay, Towards Restoring the True Text of the Old Testament: Proving, That the Canticles Is Not a Sacred Book of the Old Testament; nor Was Originally Esteemed as Such, Either by the Jewish or the Christian Church. London: J. Senex.

Whiston, William. 1724. The Literal Accomplishment of Scripture Prophecies: Being a Full Answer to a Late Discourse, of the Grounds and Reasons of the Christian Religion. London: J. Senex and W. Taylor.

Whiston, William. 1755. A New Theory of the Earth, from its Original, to the Consummation of All Things, where the Creation of the World in Six Days, the Universal Deluge, and the General Conflagration, as Laid Down in the Holy Scriptures, are Shewn to Be Perfectly Agreeable to Reason and Philosophy. London: J. Whiston and B. White, at Mr. Boyle's Head in Fleet-Street.

Williams, Megan Hale. 2008. “Lessons from Jerome’s Jewish Teachers: Exegesis and Cultural Interaction in Late Antique Palestine." In Jewish Biblical Interpretation and Cultural Exchange: Comparative Exegesis in Context, edited by Natalie Dormann and David Stern, 66-86. Philadelphia: University of Pennsylvania Press.

Wolfson, Elliot. 2001. "Messianism in the Christian Kabbalah of Johann Kemper.” In Millenarianism and Messianism in the Early Modern European Culture: Jewish Messianism in the Early Modern World, edited by Matt D. Goldish and Richard H. Popkin, 139-187. New York: Springer. 